Tér és Társadalom 1. évf. 1987/3. 99-102. p.

KRÓNIKA

\title{
KONFERENCIA A SAJÁTOS HELYZETÚ TÉRSÉGEK FEJLESZTÉSI GONDJAIRÓL
}

Az MTA Regionális Kutatások Központja 1986. november 4-5én több társadalmi, állami és tudományos szervezettel, valamint a Berzsenyi Dániel Tanárképző Fooiskolával karöltve közös konferenciát rendezett Szombathelyen „Sajátos helyzetú térségek terület- és településfejlesztési problémái" címmel. A tanácskozás, amelynek a Vas Megyei Múvelődési és Ifjúsági Központ adott helyet, jó alkalom volt arra, hogy a földrajzkutatók, a településtervezéssel foglalkozók és a regionális problémák megoldásában valamilyen módon érdekelt szakemberek beszámoljanak tapasztalataikról és kicseréljék véle ményüket számos, a kutatási területüket érintō kérdésról.

A konferencia plenáris üléssel kezdődött. GONDA GYORGY nyugalmazott államtitkár köszöntötte a résztvevốket, majd BORS ZOLTẢN, Vas megye Tanácsának elnöke nyitotta meg a tanácskozást.

Rövid beszédében vázolta a megye történelmi fejlődését, kiemelve a felszabadulástól hapjainkig megtett utat. Külön szólt Vas megye egyes térségeiről, felhiva a figyelmet azok sajátos helyzetére, eltérô fejlettségứ fokára és különböző funkcióira. Végezetül néhány mondatban ismertette a megyei területfejlesztési politika főbb vonásait, amiben kiemelt célként szerepel az idegenforgalmi és az üdülőfunkció kiteljesítése.

Az elöadások sorát ENYEDI GYÓRGY akadémikusnak, az RKK fóigazgatójának nagy érdeklődéssel várt felszólalása nyitotta meg. ENYEDI akadémikus „A hazai terület- és településfejlesztési kutatások súlypontjai" címú előadásában elsőként arról a három alprogramról beszélt, amelyek keretében a regionális kutatásokat folytatni kell (fejlödési folyamatok elemzése, urbanisztikai kutatások bóvítése, a területi tervezés korszerúsítése és szabályozása), majd a települések fejlödésében alapvetố szerepet játszó tényezök értékelésére tért rá.

Mindenekelött azokról a gondokról szólt, amelyek a vidéki ipartelepités során jelentkeztek (például a korszerútlen eszközállományú, elavult, eladhatatlan termékeket gyártó üzemegységek kisvárosokba, falvakba való kitelepítése hosszabb távon nem javít az ott munkát vállalók, illetve a település anyagi helyzetén; az iparirányítási posztokon nem változott a koncentráció mértéke, így több vonatkozásban csak látszólagos decentralizációról beszélhetủnk stb.).

Fokozza a nehézségeket, hogy a 80-as évek közepére a mezógazdasági fejlesztés - mint egyik alapvetően fontos területfejlesztő eróforrás - megújulási képessége sok területen megszúnt, és az innen származó jövedelmek megcsappanása miatt nem lehet számítani hosszabb távon a településfejlödés ilyen megalapozottsågára.

A harmadik erőforrás, a vidéki szellemi potenciál területfejlesztő szerepe egyrészt az óriási mértékü (kb. $80 \%$ - $)$ ) budapesti koncentráció, másrészt a szellemi centrumok kedvezôtllen területi elhelyezkedése miatt igen korlátozott. Mindezek következtében a területi folyamatok feltárására a korábbinál nagyobb gondot kell fordítani, és törekedni kell annak felderítésére, hogy milyen új eszközök válthatnák fel, illetve egészithetnék ki a területfejlesztés jelenleg vészesen fogyó erôforrásait.

LACKÓ LÁSZLÓ, az ÉVM fôosztályvezetôje is sürgette előadásában a kutatási tevékenységek megújításának szükségességét, a sajátos helyzet létrejöttének feltárását. Felhivta a figyelmet arra, hogy a jelenleg rendelkezésre álló statisztikai adatok nem megfelelöek, illetve nem elegendőek megalapozott területfejlesztési döntések megvalósítására. Ovatosságra intett a határmenti térségek kutatásánál a vizsgálandó terület elhatárolásával kapcsolatban, megemlítve az átmeneti zónák fontos szerepét az elemzésekben. Idézte az Országgyúlés 1985 -ös, területfejlesztéssel kapcsolatos állásfoglalásait, és feladatként jelölte meg a kutatók számára az elemzéseken alapuló fejlesztési javaslattételt és ajánlásokat. 
Tér és Társadalom 1. évf. 1987/3. 99-102. p.

A plenáris ülés utolsó előađója ERDóSI FERENC, az RKK tudományos osztályvezetője volt, aki a határmenti térségek kutatásának cél- és eszközrendszerét vázolta felszólalásában, részletezve a különböző tudományágak feladatait a területi kutatások komplexitásának növelésében, az interdiszciplináris valóságfeltárás érđekében. Jól felépített előadásában a természeti viszonyoktól kezdve a technikai, gazdasági viszonyokon át a müvelődési-kulturális szféráig tételesen felsorolta azokat a konkrét kutatási irányokat, amelyek segítségével mód nyílik a határmenti folyamatok feltárására, s a ma még többnyire hátrányos helyzetú területek fejlesztésének megalapozására.

A konferencia ezután két szekcióban - 1. határmenti térségek, 2. speciális térségek KRAJKÓ GYULA, illetve TÓTH JÓZSEF elnökletével folytatta munkáját. A szekcióüléseken a rendelkezésre álló iđôhöz képest igen sok (összesen 38$)$ rövid (10-15 perces) előadás hangzott el, így csak arra volt iđő, hogy a felszólalók vázlatszerüen ismertessék a témával kapcsolatos mondandójukat. Sajnálatos, hogy a konferenciák fontos részét jelentő vitára - leszámítva néhány rövid kérdést és megjegyzést - már nem kerülhetett sor. Ưgy tünik, hogy az utóbbi években a regionális tudományos tanácskozásokon ez a túl sokat markolni akaró, de ehhez elegendő idő nem biztosító káros gyakorlat rendszeressé válik, a résztvevók bánatára...

Az első szekcióban lényegében az országhatár menti területek fejlesztési problémái kerültek terítékre. Az elsỏ felszólaló, ZALA GYORGY előbb a határmenti régiók kialakulásának történelmi előzményeivel foglalkozott, majd a kétoldalú nemzetközi kapcsolatok fejlesztésében rejlő lehetőségek kiaknázását szorgalmazta, különös tekintettel a növekvő idegenforgalom kihasználására.

BERENYI ISTVÁN az MTA Földrajztudományi Kutatóintézetében nemrég elkezdődött munkáról számolt be, amelynek során a kutatók lépésról lépésre összeállítják a határmenti területek kutatásának szociálgeográfiai szempontjait. Az elóadó bemutatta a csehszlovák - magyar határ egyik észak-magyarországi szakaszának speciális demográfiai térképsorozatát, amely már jelentős részben szociálgeográfiai módszerek felhasználásával készült.

BOCCSKEY FERENC a történelmi múltba visszanyúlva elemezte Vas megye határmenti térségei sorsának alakulását, kitérve a határvonalváltozás városi vonzáskörzeteket szétszabdaló negativ hatására, és a megye falusi térségeinek legégetőbb mai gondjaira (pélđául elmaradott infrastruktúra, munkaalkalom hiảnya stb.).

BRUHẢCS JÁNOS a nemzetközi jog oldaláról vizsgálta a határmentiséget. Szemléletesen tárta föl a problémakörhöz tartozó megannyi jogi szabályozás nehézségeit, a határvizek fölötti felségjogtól kezdve egészen a telekommunikációs helyzet (televíziózás, rádiózás) szerződéses szabályozásáig. A nemzetközi együttmúköđẻs határmenti kibontakozását gátló tényezỏk között az egyik legfontosabbnak a túlságosan centralizált külügyi jogi szabályozást említette.

FODOR ISTVẢN az országhatáron átjutó, környezetet (elsősorban a levegôt és a vizet) szennyező anyagok által okozott gondokról beszélt. Hangot adott annak a véleményének, hogy ideje volna a határmenti térségekre vonatkozóan is a környezetterhelési térképek elkészítése, amelyeken fel lennének tüntetve az ,importált", illetve ,exportált" szennyezőanyagok legfőbb jellemzôi. A felszólaló az iparszegény területek növekvő víz- és talajszennyezódésének elsődleges forrásaként az infrastrukturális elmaradottságot jelölte meg (például a csatornahálózat hiányát).

FRISNYẢK SÄNDOR a ,periféria perifériájának”, azaz Szabolcs-Szatmár megye határmenti területeinek sokrétú gondjairól számolt be térképekkel szemléltetett elöadásában. Utalt a Délkelet-Nyírség, a Szatmári- és a Beregi-síkság forgalmi elzártságára, a foglalkoztatási nehézségekre, az életkörülményeknek az Alföld átlagától való lényeges elmaradására. Fölvetette a Szovjetunió kárpát-ukrajnai területeivel való együttmüköđést mint jövőbeni lehetőséget a kedvezó folyamatok megindítására.

ZÁKONYI JÁNOS a határmenti területek vízgazdálkodásában megvalósuló nemzetközi együttmúködést ismertette, amit a hatékony vízrendezés érdekében a Duna vízgyưjtőjének egészére ki kellene terjeszteni. Az új rendszer felválthatná az eddigi kétoldalú, sok esetben nem eléggé összehangolt nemzetközi vízügyi egyezményeket és valamennyi érdekelt ország számára hasznot hozna.

HAJDƯ ZOLTẢN új szinfoltot hozott a szekció munkájába, amikor a határmenti térségek politikai-földrajzi kutatásainak bövitését szorgalmazta, történelmi távlatokban szemlélve a 
mai helyzet kialakulásához vezető utat. Rámutatott, hogy a történelmi-politikai gyökerek feltárásával igen sok vonatkozásban érthetôvé válik a Monarchia utódállamainak a nemzetiségekkel, a határmenti térségekkel kapcsolatos reagálása még napjaink politikai gyakorlatában is.

KOVACS TEREZ is további szempontokkal gazdagitotta a téma vizsgálatát, amikor felvázolta azokat a legnagyobb problémákat okozó jelenségeket (elöregedés, elvándorlás, a cigányság helyzete), amelyek indokolttá teszik e térségeknek más, dinamikusabb területekkel való összehasonlító szociológiai elemzését.

ROTTLER FERENC pedig a határmentí területek nemzetiségeinek identitástudatával kapcsolatos megfigyelésekről számolt be dióhéjban.

SIMON IMRE elỏadásában nem az országhatár, hanem a megyehatár menti területekkel foglalkozott, megjegyezve, hogy e részeken az elmaradottság felszámolására talán kedvezóbbek a feltételek, mivel a tennivalóknak nincs nemzetközi vonatkozása, és az elmaradottság ok-okozati rendszerének feltárása is könnyebben megoldható, mint az országhatár menti területeken.

Meghatározott térségek gondjairól szóltak elỏadásukban IVANCSICS IMRE (a jugoszláv-magyar kishatárforgalom jogi szabályozásáról), KẢROSSY CSABA (az ôrségi területek tömegközlekedési térkapcsolatairól), RECHNITZER JÄNOS (Győr-Sopron megye határmenti együttmúködési kapcsolatairól) és SUULI-ZAKAR ISTVĀN (Ëszakkelet-Magyarország falvainak fejlödésbeli különbségeiről).

A speciális térségek problémáival foglalkozó szekcióban kilenc felkért hozzászóló fejtette ki véleményét. A korreferátumok egyik súly ponti kérdésköre a speciális térségek fogalmának értelmezése volt. Többen megfogalmazták, hogy tulajdonképpen minden területi egy ség sajátos, ha úgy tetszik speciális, noha a sajátos és speciális jelzót például BOROS FERENC ebben a tekintetben nem szinonimaként értelmezte. A kutatások számára mégis szükséges megvonni a szúkebben yett speciális térségek fogalmi határait. Egyes hozzászólók (BOROS FERENC, KÖSZEGFALVI GYOORGY, NOVÁK ZOLTĀN) fontos és vizsgálandó területként az agglomerációkat emelték ki, mig mások a hátrányos vagy halmozottan hátrånyos térségeket (CSAPÓ TAMĀS, FARAGÓ LÁSZLÓ, HRUBI LÁSZLÓ). MÉSZÁROS REZSÓ a városok hoz csatolt falvak sorsának sajátosságaira hívta fel a figyelmet, utalva arra, hogy a statisztikai adatbázisok szükössége miatt nagyon nehéz a téma kutatása.

A korreferátumok másik lényegi kérdésköre a kutatási elózmények bemutatása, azaz egy-egy térség vizsgálati eredményeinek összefoglalása volt. CSAPÓ TAMẢS a nyugati határmenti térségek közül a hátrányos helyzetúek jellemzésére vállalkozott. FAZEKAS PÉTER pedig két kisebb településcsoport részletesebb elemzéséról adott számot. FARAGO LẢSZLO - HRUBI LẢSZLO a többszörösen hátrányos helyzetü baranyai falvakra készített elemzés általános tapasztalatait értékelte, utalva a kialakulási folyamatra és ezzel együtt a hátrányos helyzet feloldásának lehetőségeire. NOVẢK ZOLTẢN az agglomerálódó térségek közül a vidéki városok körüli agglomerációkra hívta fel a figyelmet.

A harmadik csomópont az elvi, módszertani problémák értelmezése volt. KôSZEGFALVI GYOORGY az agglomerációk vizsgálatával kapcsolatban három kérdésre hívta fel a figyelmet: az agglomerációk elónyeire, az irányítás problémáira, a sajátos fejlesztési koncepciók kimunkálásának szükségességére. DOBOS TIBOR a környezetgazdálkodás szféráját vizsgálta. PAPP ANTAL a sajátos térségek kutatásának néhány súlyponti kérdését taglalta, rámutatva a modellszerú megközelítés fontosságára is. A felkért hozzászólók után még tizenegyen fejtették ki nagyon röviden vélemén yüket a vita során.

A szekcióban elhangzottak sokirányúsága összességében rávilágított arra, hogy bár jelentős kutatási elốzményekre, eredményekre támaszkodhatunk, a feladat sikeres megoldásához nagyon sok alapkutatásra van szükség. A szekcióüléseket záró plenáris ülés követte, ahol a szekcióelnökök értékelték a végzett munkát, majd az első nap GONDA GYƠRGY zárszavával ért véget.

Másnap a tanácskozás résztvevói szakmai terepbejáráson vettek részt a SzombathelySzentgotthárd-Farkasfa-Szalafó-Óriszentpéter-Velemér-Körmend-Szombathely útvonalon. Szentgotthárdon a városi tanács elnöke beszámolt a város gazdasági életérôl és a határmenti településekre kifejtett vonzóhatásának változásairól. larkasfán meglátogattuk az ország három radarmeteorológiai állomásának egyikét, ałol az állomás vezetője ismertette a $300 \mathrm{~km}$-es hatósugarú rendszer múködését és a hazai meteorológiai megfigyelésekben játszott fontos szerepét. Felkeres- 
tük a híres szalafői Pityerszert, az Ớrség népi építészetének emlékét, és időztünk egy keveset Velemér Årpád-kori múemléktemplománál is. Szívélyes fogadtatásban volt részünk az Ơrség „fövárosában", Óriszentpéteren, ahol a tanács elnöke meleg szavakkal köszöntötte csoportunkat, és lelkesen beszélt a községről, a növekvő népességről, a gazdasági fejlödés feltételeirôl és a térség idegenforgalmi szerepkörének bővüléséról. A terepbejárás a körmendi Batthyány-kastéllyal való rövid ismerkedéssel ért véget.

A szombathelyi konferencia valamennyi résztvevője eredményesnek ítélhette meg a tanácskozást, amely jól érzékeltette azt a szerteágazó feladatot, amit a határmenti és speciális térségek kutatása jelent valamennyiünk számára. Igy a mintegy 200 szakember hasznos tapasztalatokkal távozhatott Vas megye székhelyéról.

Külön köszönet illeti a szervezóket a tanácskozás gördülékeny lebonyolításáért és azért a szives vendéglátásért, amelyben valamennyiünket részesítettek a két nap során.

A konferencia anyagát a szervezók gyưjteményes kötetben jelentetik meg.

HRUBI LÁSZLÓ - TINER TIBOR 